\title{
Volcanoes Disaster Risk Reduction in Science Education Curriculum A Systematic Review
}

\author{
Rizki Arumning Tyas ${ }^{1 *}$, Pujianto ${ }^{2}$, Suyanta ${ }^{3}$ \\ ${ }^{1,2,3}$ Yogyakarta State University, Indonesia \\ "Corresponding author.Email: rizki.arumningtyas@gmail.com
}

\begin{abstract}
As a country with 129 active volcanoes, Indonesia has very high potency against volcanic disasters. The high risk of disaster has been offset by the high preparedness of society in the face of disaster. One of disaster risk reduction efforts can be trained through the education sector, which is through the integration of volcano material and its knowledge into science learning at the junior high school level. This is a systematic literature review research. This article is purposed to: (1) Do a review of basic disaster awareness in educational contents, (2) Do a review about the integration of volcanoes disaster risk reduction in science learning, and (3) Produce an evaluation instrument of volcanoes disaster risk reduction in science learning. The results obtained are: (1) Basic disaster awareness in educational contents embodied in the disaster management cycle that consists of prevention and mitigation, preparedness, response, and rehabilitation and reconstruction. These four aspects divided into activities undertaken on pre-disaster, during-disaster, and after-disaster, (2) Integration of volcanoes disaster risk reduction in science learning can be conducted through basic competence of 3.10 and 4.10 in $7^{\text {th }}$ grade of Junior High School with the main topic of Volcano and its risk reduction, and (3) evaluation instruments of volcanoes disaster risk reduction in science learning contain four aspects; knowledge and attitudes toward disaster risk, early warning systems, plans for disaster emergency, and resource mobilization that can be realized through assessment test or questionnaires.
\end{abstract}

Keywords: Volcanoes, Disaster Risk Reduction, Science Education.

\section{INTRODUCTION}

Landscapes in Indonesia vary considerably. There is a configuration both horizontally and vertically, which leads to the movement of unstable tectonic plates [1]. Geographically, Indonesia has three main plates, such as the Indo-Australian that moves northwards, the Southeast Asian moving southeast, and the Pacific that moves westward. The three plates meet each other at Triple Junction [2].

Indonesia is known as an archipelago with approximately 5,590 river basins, resulting in Indonesia being one of the high-risk countries against the threat of earthquakes, tsunami, volcanic eruptions, and land movements [3]. Indonesia is a country with 129 active volcanoes, where the number refers to the country with the highest number of active volcanoes in the world. The volcano is located in a series of volcanoes known as the ring of fire [4].
Until now, the government and the public are still struggling to find efforts to overcome any problems related to the disaster of volcanic eruptions. Some people are still lacking in understanding what actions they should do in the event of a disaster, what to prepare during the disaster, and how to reduce the risk of the disaster. The disaster handling Model is still reactive, meaning that the government can't give early detection when a disaster occurs. Indonesia is a country with fifth largest population in the world, but the society has not reflected the disaster-resilient society, seen from the knowledge and attitude toward disaster [5].

The government together with the community should change the paradigm of disaster management in five aspects, namely responsive action to preventive action, sectoral programs to multi-sectoral programs, government responsibilities are solely a joint responsibility, centralized centralization mechanism, as well as from emergency response to risk reduction [6]. Therefore, all people need to know how to reduce the 
risk of volcano eruptions, by studying the mitigation of volcano eruptions.

Society is the most vulnerable element to the main object in the event of a disaster. People must understand the susceptibility of disaster risk so that people can be the main subject in disaster risk reduction efforts. Disaster risk becomes high when society can't respond to the danger of the eruption due to a lack of understanding of the volcano and its dangers [7].

The Law of the Republic Indonesia No. 24 of 2007 on disaster relief in article 6 explains that government responsibilities in the implementation of disaster management include disaster risk reduction and complaint reduction disaster risk with the development program. Education as one of the development programs can be a deciding factor in disaster risk reduction activities. This shows that education becomes an effective means of suppressing disaster risk by including disaster materials, especially for schools located in the catastrophic risk area [8].

School of disaster Education is a way of creating good knowledge, conducive situation, awareness-raising and strong attitude facing disaster through the integration of disaster materials in formal and informal education [9]-[11]. Implementation of disaster learning at the school level includes three aspects, namely empowering institutional and community capacity roles at school level, integration of disaster materials into the school curriculum, and the creation of partnerships from various parties to support the implementation of disaster education in school level. It also encourages students to hone their knowledge and skills, to contribute proactively in disaster prevention and mitigation [9], [12].

Educational institutions can integrate disaster materials into natural science subjects in junior High School. In addition to creating a generation of conscious and resilient disasters, this integration is also able to encourage the achievement of long-term national development plan aimed at creating an independent, forward, fair, and prosperous society. Education is one of the effective means to support disaster risk reduction efforts. Material analysis is required before the integration of disaster materials into subjects. The analysis of the material aims to determine what volcanic material can be used to support the risk reduction efforts of volcano eruption. This article is purposed to: (1) Do a review of basic disaster awareness in educational contents, (2) Do a review about the integration of volcanoes disaster risk reduction in science learning, and (3) Produce an evaluation instrument of volcanoes disaster risk reduction in science learning.

\section{DISCUSSION}

This research is aimed to find out the various risk of volcanic eruption. After identifying the various risks and impacts incurred, efforts can be made to reduce the high risk, especially concerning the integration of disaster risk reduction in the education sector.

\subsection{Basic Volcanoes Eruption Disaster Awareness in Education}

Volcano is a manifestation of the past internal dynamics to the present of the planet Earth which is also a major natural danger [13]. Volcano is one of the face of the earth which is the place where the process of vulcanism or the magma release to the Earth's surface. The volcano is categorized under active circumstances when there are activities in it that are monitored with volcano vibration monitoring tools. Volcanic eruption is a major natural danger on earth, especially in areas with significant population density. Volcanic eruption is one of the natural disasters that come from the bottom of the layer or the Earth's surface which is a common disaster and included in the major Disasters [14].

Common symptoms that characterize volcanic eruption, such as the emergence of hot clouds of the mouth of the mountain accompanied by strong sulfur odours, there is a local volcanic earthquake in a tightly frequency arising from the mountain belly as a result of the magma movement, and the mountain animals descend to the foot of the mountain. The various dangers caused by volcanic eruption are as follows.

- Volcanic ash is a mixture of lava fragments with sand formed from the active dome. The shape and size of volcanic ash can be used to identify the magma composition [15].

- The hot clouds is a carriage that strikes through valleys and mountains, where the volume is dropped and consists of a large, glowing lava block and moves rapidly. The temperature of the hot clouds reaches $450^{\circ} \mathrm{C}$ at a speed of $15-20 \mathrm{~m} / \mathrm{s}$ [7].

- Lava Dome, a thick magma formed from silica, andesite, and very acidic. The lava dome shape is influenced by the configuration of the lava site extruded. The lava dome grows with the increase in energy from the stomach of the mountain so that the outer layer is stretching. The end of the Lava dome formation will form a depression at its peak. This depression is the result of various factors, such as depreciation by cooling, or the stop of pressure upward [7].

- Lava flows, a liquid or semi-liquid material with a temperature of $900-1200^{\circ} \mathrm{C}$ that comes out to the surface of the Earth-shaped liquid material to squirt. The lava flows contain sulphur dioxide and drip acid sulfate aerosol. $\mathrm{HCl}$ (hydrochloric acid) and $\mathrm{HF}$ (hydrofluoric acid) are also found in lava flows especially when liquid lava bumps into the ocean, thereby creating acid rain from Steam [16].

- Pyroclastic fall, is a very hot flow of gas and scattered debris which can move at a speed above $350 \mathrm{~km} / \mathrm{h}$. Pyroclastic drops arise from the collapse of eruption column or Lava dome. Pyroclastic falling temperature can reach $1000^{\circ} \mathrm{C}$. Gas content in 
pyroclastic drops include $\mathrm{H} 2 \mathrm{O}, \mathrm{CO}_{2}, \mathrm{SO}_{2}$, and $\mathrm{H}_{2} \mathrm{~S}$ [16].

- Volcanic Gas emissions is a vapor of magmatic and superficial sources, e.g. $\mathrm{CO}_{2}$ Gas, $\mathrm{H}_{2} \mathrm{~S}$, and radon. Volcanic Gas can cause harm to human health. Volcanic gas can be carried away by volcanic ash that has a high uranium content and carries radon particles as well as radioactive gas [16].

In addition to various dangers, volcano eruption will certainly harm the surrounding community. Volcanic eruption could cause a disruption of calmness, life patterns, and the life expectancy of society because of the loss of ease or excrete wealth owned, both the form of living objects such as family members, livestock and plants, and dead objects, houses, farms and the rice field eruption volcano also destroys the means of Asrigita and interfere with the socio-economic activities of the community. Education is also interrupted due to damage to education facilities [17], [18].

To reduce the risk of volcano eruption, systematic and continuous efforts are required. One of the efforts that can be done is to integrate the training of disaster preparedness and awareness in the school learning. Three basic skills must be possessed to become conscious and resilient disaster, namely knowledge, skills, and disaster preparedness [19]. Knowledge can be gained through participation in disaster training. Skills and preparations relate to the preparation of individuals, families, and communities in the event of a disaster. Disaster preparedness is an integral part of various supporting aspects, such as protection of life safety, facilities protection, infrastructure, and food security, emergency home supplies, knowledge and attitudes towards disaster risk, and the resilience of public groups to disasters [20].

Individuals or public groups who are alert to disasters must master various competencies, such as preparing important supplies, having evacuation plans, standby and familiar with warnings, caring for family safety, being alert and familiar to evacuation orders, preparing emergency plans, recognizing and avoiding the risk of harm, mastering first aid, and must learn from previous experiences [21]. The disastrous attitude is directly proportional to the action given, such as training and habituation to become tangled to disasters. So, the more often individuals or groups are given training and habituation with preparedness, the higher the disaster will face [22]. Thus, it is needed to more stressed in post-disaster preparations. In addition to preparing for knowledge and skills on how to deal with disasters, post-disaster preparation should not be forgotten. It aims to face the worst possible after a catastrophic occurrence [23].

The cycle of disaster risk management is divided into four phases, namely phase prevention or mitigation, readiness, response, and recovery [24]. Meanwhile, the other source mentions that disaster risk management consists of three phases, namely assessment and planning, physical and environmental protection, and community development response [25]. It is also different from the other source which emphasizes simulation, socialization, and post-disaster infrastructure development [26].

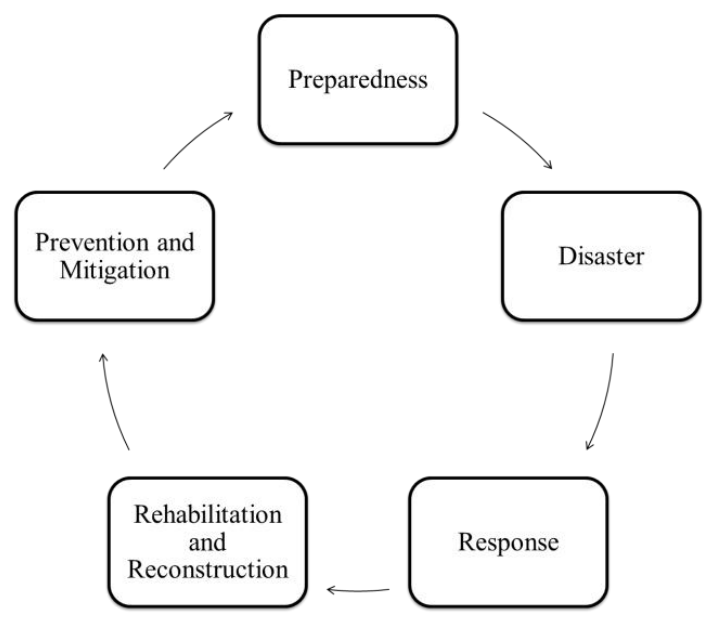

Figure 1 Disaster Management Cycle

- Mitigation is an efforts to reduce disaster risk, either through physical development or awareness and enhancement of disaster-facing threats. Mitigation is done to reduce disaster risk for communities in disaster prone areas. Mitigation is the stage or step of the risk emits caused by disaster [27]. In mitigation there are two important parts, namely the reduction and prevention of the high risk of disaster [28]. Prevention or mitigation is to avoid the impact of adverse harm by reducing exposure or reducing human vulnerability to hazards that may pose a risk [24].

- Preparedness focuses on actions undertaken earlier or during the early stages of the disaster to reduce its impact, increasing population resilience [24]. Preparedness may include planning (completing a vulnerability analysis of hazards), training and simulation, public education, policy-making e.g. zoning, inventory and equipment inventory, identifying alternative care venues for health, planning for crisis management, supervision, as well as a long-term plan arrangements including postdisaster recovery [29]. Disaster preparedness is often referred to as the act carried out before events to reduce and eliminate the severity of natural disasters by preparing the community through the development of emergency plans for response and recovery [22].

- Shortly after the disaster occurs, a quick response is required to address the higher negative impacts that arise. The steps of response are actions that provide emergency services and public assistance during or shortly after a disaster to save lives, reduce adverse health impacts, ensuring public safety, and providing basic needs for affected persons [30]. Disaster management in response phase includes rescue and 
evacuation of affected communities, fulfillment of basic needs, protection against vulnerable groups, and recovery of vital facilities and infrastructures [31].

- Rehabilitation and reconstruction aims to restore affected area conditions to normal conditions and rebuild the damaged facilities and infrastructure in a better disaster [32]. Rehabilitation and reconstruction is an activity aimed at improving and improving the living standards of the affected communities through the improvement of facilities and infrastructure, improving the social economic conditions of the affected communities, improving the functioning of public services and services in the community, and restoring the psychological conditions of the affected communities.

One of the factors determining the success of disaster risk reduction efforts in education is the creation of resilience in schools as an educational institution. Schools with resilience to disasters have several indicators, such as being able to embed ties between schools, providing cooperative and consistent support for the improvement of the resilience of the school to disaster, teaching life skills, creating a caring and supportive environmental climate, always coordinating and communicating with other institutions, and opening opportunities for all the school residents to develop themselves, of course with the same direction and objectives that is for the creation of the school and a tough school citizen of disaster [33].

Disaster risk reduction efforts in education emphasize the knowledge and skills that students must master concerning disaster management [34], [29]. Also, how students see and apply their preparedness for the success of disaster management in school is also the focus that must be trained. It needs to be trained to respond to students in the event of a disaster. The student's definition of disaster is also to be likened, it aims that all school citizens, especially students as the most dominant component in the school community, have the same perception of disaster, so that it can synergize common goals, namely the disaster-resilient schools. Based on the explanation above, gained knowledge and basic skills about disaster risk reduction efforts that must be trained to the learners. This includes the knowledge and basic skills that exist and must have before the disaster, disaster, and after the disaster. Each of these stages contains anything to do with regards to the volcano eruption.

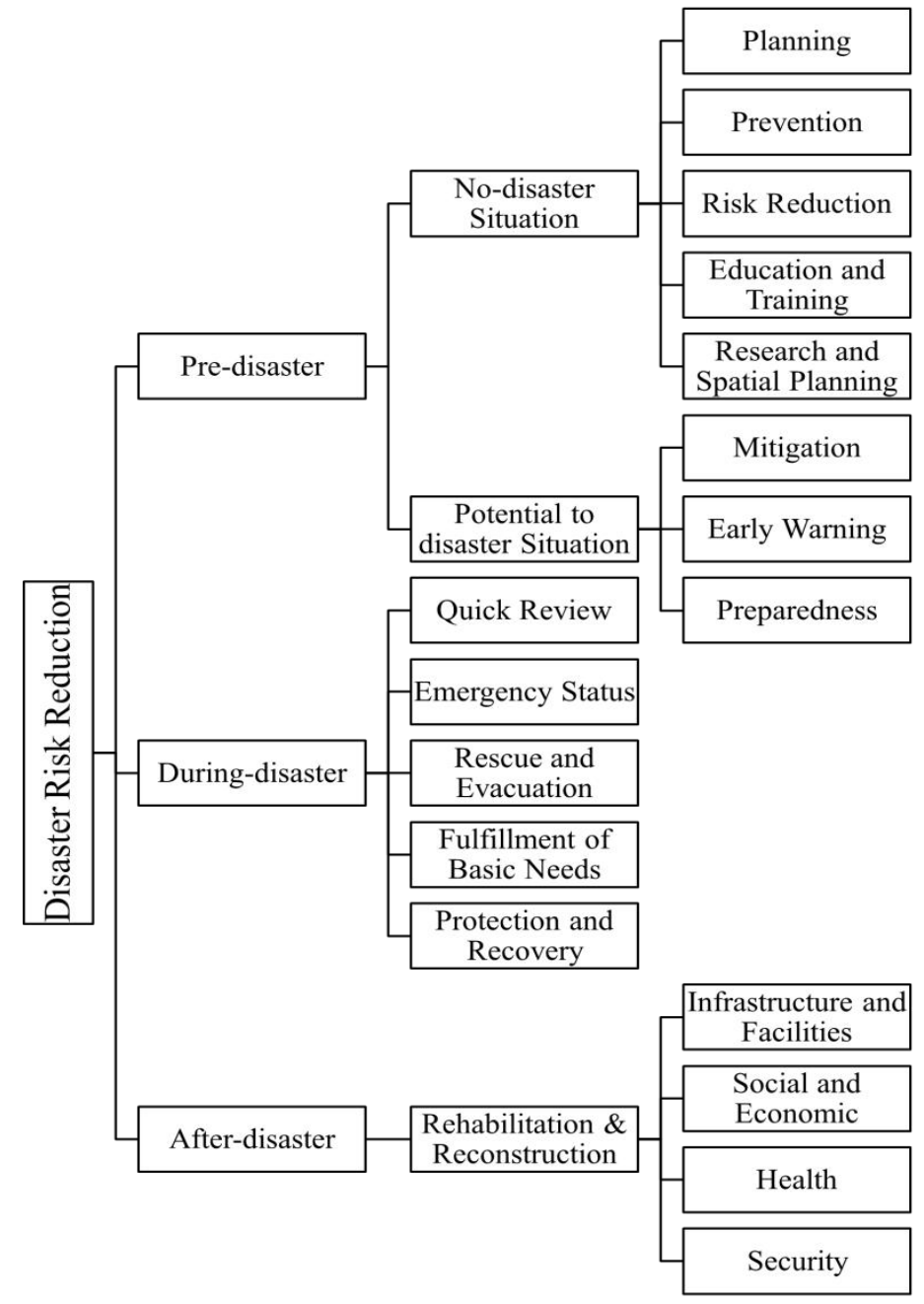

Figure 2 Disaster Risk Reduction Efforts: Pre, During, and After Disaster 


\subsection{Volcanoes Disaster Risk Reduction in Science Learning}

Natural science has benefits for human beings and can maximize the environment to be continuously dug and useful as long as it is not abused. Natural science is a study that includes the field of energy forms and its changes, space earth, living creatures, life processes, and the material and nature that play a role in helping learners to understand the natural phenomena that have the four main elements are attitudes, processes, products, and applications and have three dimensions of science as a way of thinking, science as a way to investigate, and science as the body of knowledge. Besides, Natural science is a whole unit of products, processes and applications that can be examined philosophically through what is learned in the science, how to learn it, and what its value and usefulness for everyday life.

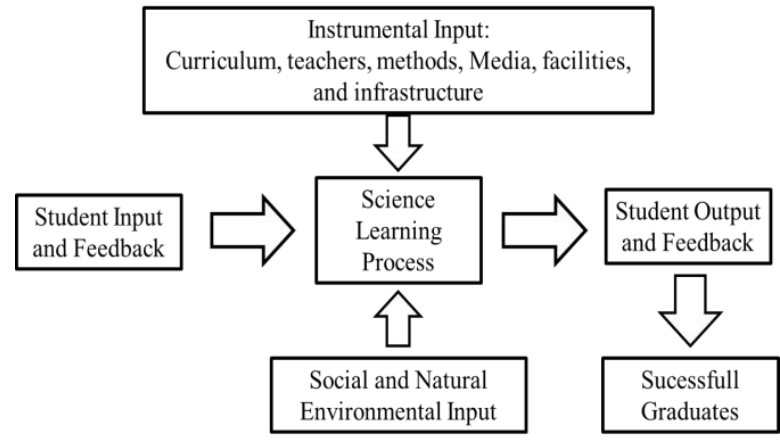

Figure 3 Science Learning System Models

Natural science studies include the realm of process, product, attitude, value, and morals. Components in the process include identifying problems, observing, drafting hypotheses, analyzing, exploring, and synthesizing. The product components include facts, concepts, theories and generalizations. The components of value and moral attitudes include high curiosity, critical, creative, humble, open-view, and recognizing the regularity of nature as God's creation. These components are a unity that cannot be separated from each other. Integrated natural science learning should facilitate the achievement of the realm.

Natural science is not only related to the knowledge of concept, fact, or principle, but natural science is a systematic process of discovery [35]. Natural science learning emphasizes on giving direct experience so that it can be a container for learners to learn about themselves and the environment. Natural science learning is expected to help students gain a deeper understanding of the environment so that it benefits the survival of everyday life.

Volcanic eruption is one of the natural phenomena studied in Natural science. Disaster risk reduction efforts of volcanic eruption can be embodied in the school to study disaster learning with subjects. Disaster studies related to volcanic eruption need to be given early so that children know how to manage disaster risk. It takes an applicative natural science learning and fosters disaster preparedness, so learners are better prepared while facing disaster conditions. Disaster studies related to volcanic eruption need to be implemented in teaching and learning activities through natural science in Junior High school, following curriculum 2013 on 7th grade, with basic competence of 3.10 that state "Understanding the Earth, volcanoes, earthquakes, and risk-reduction measures before, during, and after the disaster in the disaster-prone areas" and basic competence of 4.10 that state "Communicating the efforts of risk reduction and the impact of natural disasters, self-rescue during disasters according to the type of disaster threats in the region." The basic competencies are then outlined into several indicators of more detailed competency achievement, as follows.

Table 1. Basic Competence and Competency Achievement Indicator

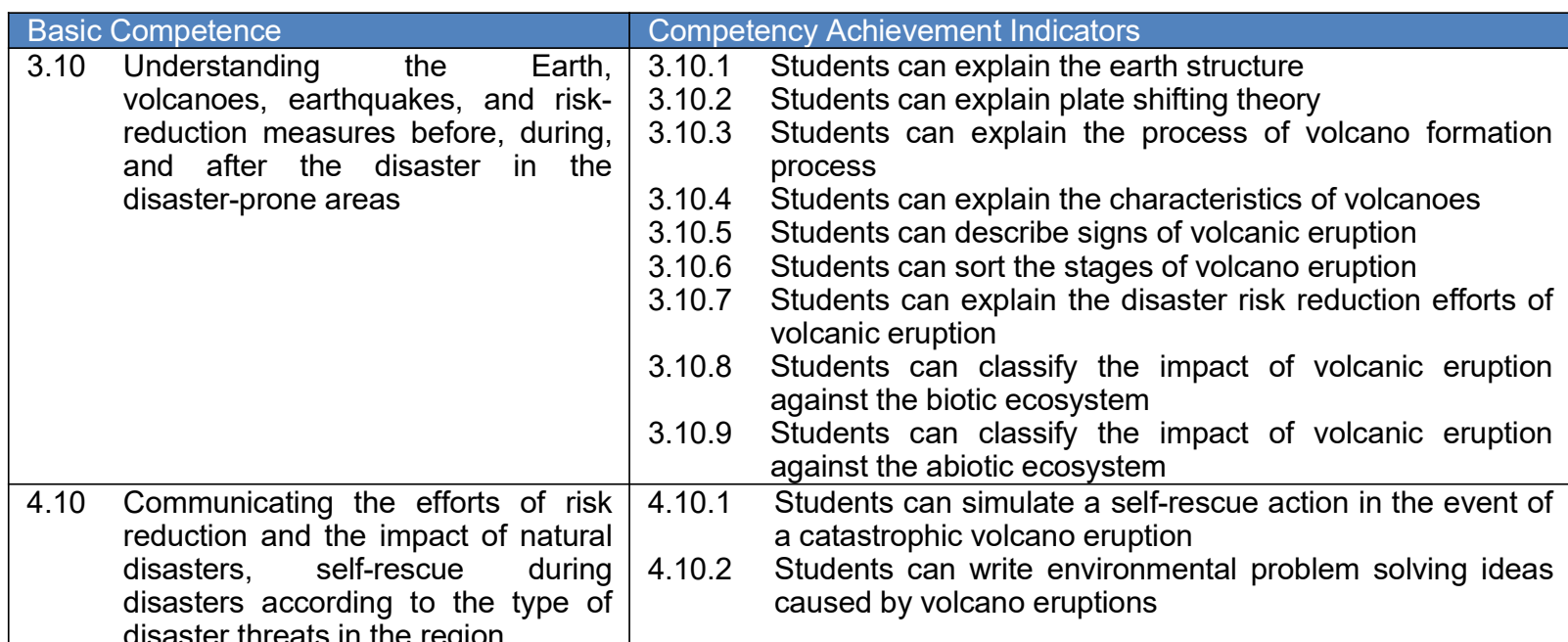

Learning is packed in a chapter with a large theme titled "Volcano and its risk reduction." Volcano and its risk reduction is divided into three sub-materials each taught at each meeting. At the first meeting the students learned the Earth's structure, shifting plates, volcanic formation, and volcano characteristics. At the second meeting, learners learn the signs and stages of volcano eruption and the risk reduction efforts of volcanic 
eruption and self-rescue actions. Meanwhile, at the third meeting the learners learn the impact of volcanic eruption on the ecosystem, both the biotic ecosystem and the abiotic ecosystem. The overall material concept map is as follows.

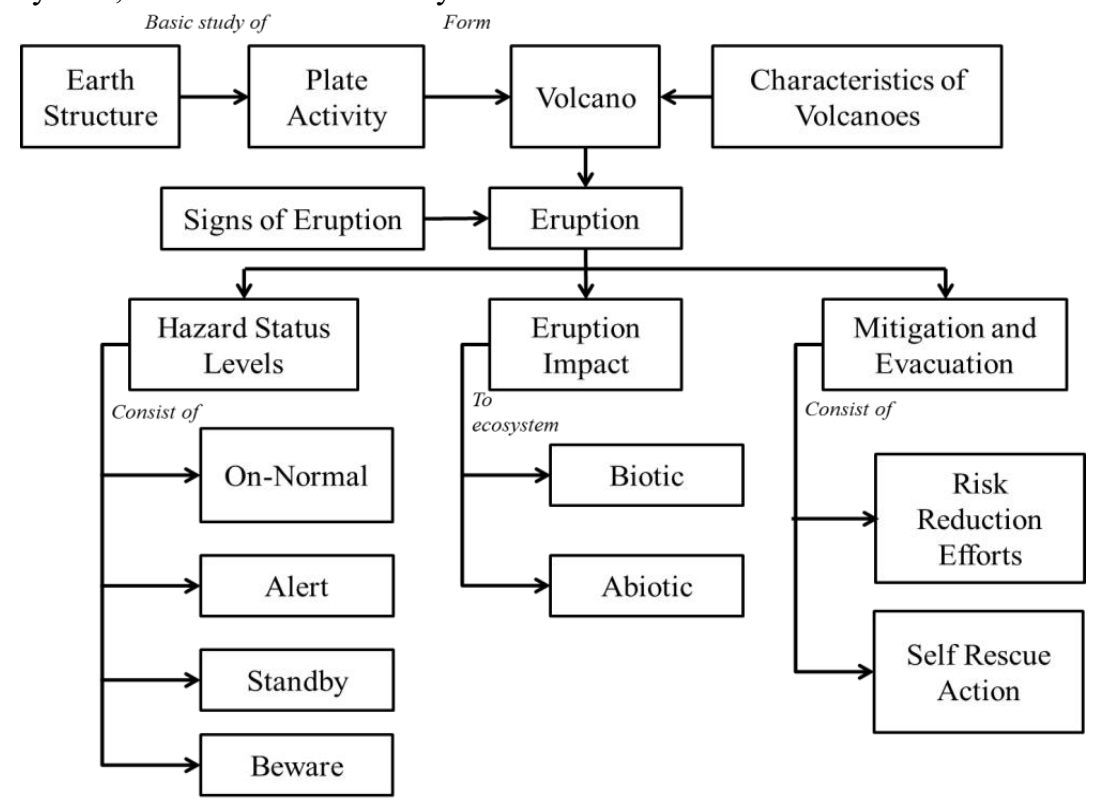

Figure 4 Volcano and Its Risk Reduction Concept Map

\subsection{Evaluation of Volcanoes Disaster Risk Reduction in Science Learning}

Every effort requires evaluation, which aims to determine the effectiveness of the business that has been done. Also, evaluation also aims to improve the quality, in this case the integration of disaster risk reduction efforts in science learning. The final goal expected from the integration of disaster risk reduction efforts in science learning is the creation of students as part of a community that is conscious, resilient, and ready to face disaster. Evaluation should measure student preparedness. Based on the analysis of the literature conducted, there are four aspects of disaster preparedness of volcanic eruption, as follows.

\subsubsection{Knowledge and Attitudes Toward Disaster Risk}

Knowledge is the key to preparedness. Increased ability and awareness of hazard-related risks leads to better understanding, improved management, and eventual goal is disaster risk reduction [36]. The knowledge is usually able to influence the attitude and concern of society to be acessible and quickly anticipate the disaster risk especially for those residing in disaster prone areas [31]. The knowledge that individuals and family must have about natural and catastrophic events includes the form, origin, consequence, and location of disasters. Besides, the physical acountability of residential buildings includes the form and infrastructure should also be understood [30].

\subsubsection{Early Warning System}

The early warning system is a series of notifications on the emergence of natural events that are conveyed to the affected community with easy-to-digest language [19]. Early warning involves delivering effective information through clear institutional institutions allowing individuals and threatened family to take measures to avoid or mitigate risk and prepare to make effective emergency response efforts [37]. Good early warning systems refer to the increase in risk understanding at either the institution or community level, monitoring potential disasters, communication and distribution of information, and Community response [20]. This can include the availability of information sources for disaster warnings from both traditional and local sources and access to disaster warning information [30].

\subsubsection{Plan for Disaster Emergency}

The plan for disaster emergencies is an activity that is done as soon as the disaster occurs to minimize the adverse effects inflicted by the disaster [20]. Planning for a disaster emergency is based on the analysis of disaster risk and its prevention efforts. The plans include recognition and assessment of hazards, vulnerability recognition, possible analysis of catastrophic impacts, choice of disaster relief action, disaster mitigation mechanisms, as well as the division of duties and roles of institutions [38]. The emergency response plan includes seven components, including the family plan to respond to emergencies: the existence of a family rescue plan (who does what) in the event of an emergency, evacuation plan includes the availability of maps, place of family evacuation route, place of the family's dull moment of disaster, the presence of relatives/family/friends who provide temporary shelter in the emergency, first aid, rescue, safety and security, 
fulfillment of basic needs, equipment and supplies, important facilities that have access with disaster, as well as training and simulation [30].

\subsubsection{Resource Mobilization}

The mobilization of resources is a participation in training related to disaster preparedness and preparations when affected by disasters [37].The success indicators of resource mobilization are seen from the collective actions of society as well as the role of some groups to move the other group [22]. Elements that support resource mobilization include synergies from Governments and communities, collaborative approaches between various community components, as well as improved resource quality [20]. A systematic and coordinated mechanism involving all parties is one of the supporting factors of resource mobilization. The mobilization of resources includes the existence of family members involved in the seminar/meeting/training of disaster preparedness, the skills of family members related to disaster preparedness, the existence of savings related to disaster preparedness, as well as the family agreement to conduct simulated exercises and monitor the disaster standby bag regularly [30].

Disaster preparedness is a condition of a society that is both an individual or a group that has physical and psychic ability in the face of disaster. Preparedness is any activity before a disaster that aims to develop operational capacity and facilitate effective response when a disaster occurs. Those aspects can be realized through assesment test or questionnaires, flexible and scalable, tailored to the needs of. The aspect and indicators that can be used to measure the level of disaster preparedness are as follows.

Table 2 Aspects and Indicators of Disaster Preparedness

\begin{tabular}{|l|l|}
\hline Disaster Preparedness Aspect & Disaster Preparedness Indicator \\
\hline Knowledge and Attitudes Toward & Knowledge about actions during a disaster \\
\cline { 2 - 2 } Disaster Risk & Knowledge about disaster management \\
\cline { 2 - 2 } & Attitudes toward disaster risk \\
\hline Early Warning System & Dissemination of warnings and mechanisms \\
\cline { 2 - 2 } & Exercise and simulation \\
\hline \multirow{2}{*}{ Plan for Disaster Emergency } & Evacuation plan \\
\cline { 2 - 2 } & First aid, rescue, and security \\
\hline Resource Mobilization & Institutional Arrangement \\
\cline { 2 - 2 } & Command System \\
\hline
\end{tabular}

Natural Science learning at grade 7 of junior high school consists of 11 basic competencies, both knowledge and skills competencies. The integration of disaster risk reduction efforts into Natural Science learning can be realized in many ways. The integration of disaster risk reduction efforts into Natural Science learning can be realized in various ways, such as the creation of interactive learning media, teaching book creation, step development and learning syntax, as well as the development of learning models and approaches. The evaluation of the success of the integration can also be realized in various instruments, while still referring to the above aspect and indicators.

\section{CONCLUSION}

School is an institutions that can equip the community to provide experience and knowledge in an integrated. A disaster-ready attitude in the face of disasters is a habituation that must be built to create a community of conscious and disaster-aware communities. The school is a disaster-prone community, therefore, efforts to improve community-based disaster management programs need to be conducted in schools, one of which is the participation of students in fulfilling disaster risk reduction activities that are integrated in teaching and learning activities in schools. This literature review involves a variety of reference sources consisting of national and international articles. Through the literature review, it is known that there are four cycles of natural disaster management as the basis for training in preparedness that must be trained to students, consisting of prevention and mitigation, preparedness, response, and rehabilitation and reconstruction. The integration of disaster risk reduction efforts in science learning is done on volcanic material and its volcanic eruption disaster risk reduction, which is discussed in science Class 7 semester 2. Meanwhile, the measuring instrument of evaluation or achievement of student preparedness can be realized in the form of test or poll assessment, consisting of four aspects, namely knowledge and attitudes toward disaster risk, early warning systems, plans for disaster emergency, and resource the that can be realized through assessment test or questionnaires.

\section{ACKNOWLEDGMENTS}

We thank to the "Direktorat Riset dan Pengabdian Masyarakat, Deputi Bidang Penguatan Riset dan Pengembangan, Kementrian Riset dan Teknologi/ Badan Riset dan Inovasi Nasional" for the funding that has been given to the completion of this research.

\section{REFERENCES}

[1] H. T. Verstappen, "Indonesian Landforms and 
Plate Tectonics," J. Geol. Indones., vol. 5, no. 3, pp. 197-207, 2010, doi: https://doi.org/10.17014/ijog.v5i3.103.

[2] H. T. Verstappen, Garis Besar Geomorfologi Indonesia. Yogyakarta: Gadjah Mada University Press, 2013.

[3] E. Supartini et al., Buku Pedoman Latihan Kesiapsiagaan Bencana: Membangun Kesadaran, Kewaspadaan, dan Kesiapsiagaan dalam Menghadapi Bencana. Jakarta: Direktorat Kesiapsiagaan Badan Nasional Penanggulangan Bencana, 2017.

[4] R. Rijanta, Hizbaron, and M. Baiquni, Modal Sosial dalam Manajemen Bencana. Yogyakarta: Gadjah Mada University Press, 2014.

[5] D. Hidayati, "Striving to Reduce Disaster Risk: Vulnerable Communities with Low Levels of Preparedness in Indonesia," J. Disaster Res., vol. 7, no. $1, \quad 2012$, doi: https://doi.org/ 10.20965/jdr.2012.p0075.

[6] Sudibyakto, Manajemen Bencana di Indonesia Kemana? Yogyakarta: Gadjah Mada University Press, 2011.

[7] M. R. Amri et al., Risiko Bencana Indonesia. Jakarta: Badan Nasional Penanggulangan Bencana, 2016.

[8] M. Desfandi, "Urgensi Kurikulum Pendidikan Kebencanaan Berbasis Kearifan Lokal di Indonesia," J. Sosio Didakt. Soc. Sci. Educ. J., vol. 1, no. 2, 2014 doi: https://doi.org/10.15408/sd.v1i2.1261.

[9] D. Selby and F. Kagawa, Disaster Risk Reduction in School Curricula: Case Studies from Thirty Countries. Barcelona, Spain: Novoprint SA, 2012.

[10] Z. Septikasari and Y. Ayriza, "Strategi Integrasi Pendidikan Kebencanaan dalam Optimalisasi Ketahanan Masyarakat Menghadapi Bencana Erupsi Gunung Merapi," J. Ketahanan Nas., vol. 24, no. 1, pp. 47-59, 2018 doi: http://dx.doi.org/ $10.22146 / \mathrm{jkn} .33142$.

[11] R. Shaw, K. Shiwaku, and Y. Takeuchi, Disaster Education. Wagon Lane, Bingley: Emerald Group Publishing Limited Howard House, 2011.

[12] P. E. Suarmika and E. G. Utama, "Pendidikan Mitigasi Bencana di Sekolah Dasar (Sebuah Kajian Analisis Etnopedagogi)," J. Pendidik. Dasar Indones., vol. 2, no. 2, pp. 18-24, 2017, doi: http://dx.doi.org/10.26737/jpdi.v2i2.327 .

[13] L. Sanchez and R. Shcherbakov, "Temporal Scaling of Volcanic Eruptions," J. Volcanol. Geotherm. Res., vol. 247-248, pp. 115-121, 2012, doi:

https://doi.org/10.1016/j.jvolgeores.2012.08.004.
[14] T. S. Rambau, L. D. Beukes, and W. Fraser, "Disaster Risk Reduction Through School Learners: Awareness and Preparedness Research Methodology," J. Disaster Risk Stud., pp. 1-11, 2012, doi: https://doi.org/ 10.4102/jamba.v4i1.61.

[15] D. Nurfiani and C. B. De Maisonneuve, "Furthering The Investigation of Eruption Styles Through Quantitative Shape Analyses of Volcanic Ash Particles," J. Volcanol. Geotherm. Res., 2017 doi:

http://dx.doi.org/10.1016/j.jvolgeores.2017.12.001.

[16] A. Cook and P. Weinstein, "Volcanic and Geothermal Processes: Health Effects," Encyclopedia of Environmental Health, 2nd Edition, no. August. Elsevier Inc., pp. 1-9, 2018.

[17] Sukandarrumidi, Bencana Alam dan Bencana Anthropogene. Yogyakarta: Kanisius, 2010.

[18] W. Sulistyorini, Anugerah Gunung Merapi. Jakarta: Depdiknas, 2005.

[19] M. S. Sangkala and M. F. Gerdtz, "Disaster Preparedness and Learning Needs Among Community Health Nurse Coordinators in South Sulawesi Indonesia," J. Australas. Emerg. Care, vol. 21, no. 1, pp. 23-30, 2018, doi: https://doi.org/10.1016/j.auec.2017.11.002.

[20] S. Sadeka, M. S. Mohamad, and M. S. K. Sarkar, "Disaster Experiences and Preparedness of the Orang Asli Families in Tasik Chini of Malaysia: A Conceptual Framework Towards Building Disaster Resilient Community," J. Prog. Disaster Sci., vol. 6, 2020, doi: https://doi.org/10.1016/j.pdisas.2020.100070.

[21] M. Teo, A. Goonetilleke, K. Deilami, A. Ahankoob, and M. Lawie, "Engaging Residents From Different Ethnic and Language Backgrounds in Disaster Preparedness," Int. J. Disaster Risk Reduct., vol. 39, no. 1, 2019, doi: https://doi.org/10.1016/j.ijdrr.2019.101245.

[22] M. K. Rañeses, A. C. Richards, J. Richards, and J. Bubb, "Measuring the Level of Disaster Preparedness in Auckland," J. Procedia Eng., vol. 212, no. 2017, pp. 419-426, 2018, doi: https://doi.org/10.1016/j.proeng.2018.01.054.

[23] C. A. Brewer, A. Hutton, K. S. Hammad, and S. K. Geale, "A Feasibility Study on Disaster Preparedness in Regional and Rural Emergency Departments in New South Wales: Nurses SelfAssesment of Knowledge, Skills, and Preparation for Disaster Management," J. Australas. Emerg. Care, no. 2019, 2020, doi: https://doi.org/10.1016/j.auec.2019.12.005.

[24] A. Medina, "Promoting a Culture of Disaster Preparedness," J. Bus. Contin. Emer. Plan., vol. 9, 
no. 3, pp. 281-290, 2015.

[25] M. Petal, "Disaster Risk Reducation Education: Material Development, Organization, Evaluation," Reg. Dev. Dialogue J., pp. 1-25, 2008.

[26] A. Rusilowati and A. Binadja, "Mitigasi Bencana Alam Berbasis Pembelajaran Bervisi Science Environment Technology and Society," $J$. Pendidik. Fis. Indones., vol. 8, pp. 51-60, 2012, doi: https://doi.org/10.15294/jpfi.v8i1.1994.

[27] Sunarto, Panduan Penanggulangan Bencana Kabupaten Kutai Barat. Yogyakarta: PSBA UGM, 2007.

[28] A. Priambodo, Panduan Praktis Menghadapi Bencana. Yogyakarta: Kanisius, 2009.

[29] A. Pinar, "What is Secondary School Students' Awareness on Disasters? A Case Study," Rev. Int. Geogr. Educ. Online, vol. 7, no. 3, pp. 315-331, 2017.

[30] J. Sopaheluwakan, Kajian Kesiapsiagaan Masyarakat dalam Mengantisipasi Bencana. Jakarta: Deputi Ilmu Pengetahuan Kebumian Lembaga Ilmu Pengetahuan Indonesia, 2006.

[31] C. M. Shreve and I. Kelman, "Does Mitigation Save? Reviewing Cost-Benefit Analyses of Disaster Risk Reduction,” Int. J. Disaster Risk Reduct., vol. 10, pp. 213-235, 2014, doi: https://doi.org/10.1016/j.ijdrr.2014.08.004.

[32] M. Favereau, L. F. Robledo, and M. T. Bull, "Analysis of Risk Assessment Factors of Individuals in Volcanic Hazards: Review of The Last Decade," J. Volcanol. Geotherm. Res., vol. $357, \quad$ pp. 254-260, 2018, doi: https://doi.org/10.1016/j.jvolgeores.2018.05.009.

[33] S. I. A. Dwiningrum, Prihastuti, and Suwarjo, "Social Capital and School Resilience for Disaster Mitigation Education in Yogyakarta Schools," $J$. Kependidikan, vol. 1, no. 1, pp. 84-99, 2017, doi: https://doi.org/10.21831/jk.v1i1.10091.

[34] D. Alrazeeni, "Saudi EMS Students' Perception of and Attitudes toward their Preparedness for Disaster Management," J. Educ. Pract., vol. 6, no. 35, pp. 110-116, 2015.

[35] M. Listyawati, "Pengembangan Perangkat Pembelajaran IPA Terpadu di SMP," J. Innov. Sci. Educ., vol. 1, no. 1, pp. 61-69, 2012.

[36] R. Spiekermann, S. Kienberger, J. Norton, F. Briones, and J. Weichselgartner, "The Disaster Knowledge Matrix: Reframing and Evaluating The Knowledge Challenges in Disaster Risk Reduction," Int. J. Disaster Risk Reduct., vol. 13, pp. 96-108, 2015, doi: http://dx.doi.org/10.1016/j.ijdrr.2015.05.002.
[37] M. Gall, K. H. Nguyen, and S. L. Cutter, "Integrated Research on Disaster Risk: Is It Really Integrated ?," Int. J. Disaster Risk Reduct., vol. 12, pp. 255-267, 2015, doi: http://dx.doi.org/10.1016/j.ijdrr.2015.01.010.

[38] N. B. Said and V. C. L. Chiang, "The Knowledge, SKill Competencies, and Psychological Preparedness of Nurses for Disasters: A Sysematic Review," J. Int. Emerg. Nurs., no. September, pp. 1-9, 2019, doi: https://doi.org/10.1016/j.ienj.2019.100806. 